\title{
An Introduction to Utilizing Community Leaders to Expand Resiliency Efforts Following a Disaster ${ }^{1}$
}

\author{
Lisa Lundy, Jacqueline Aenlle, Ricky Telg, Tracy Irani, Angie Lindsey, Ashley Mcleod-Morin, \\ Michaela Kandzer, and Phillip Stokes ${ }^{2}$
}

\section{Introduction}

In March 2020, the Southeastern Coastal Center for Agricultural Health and Safety (SCCAHS) published a State of the Science (SOS) report that focused on mental health issues in agricultural, vulnerable, and rural communities (AVRCs). The AVRCs included in this report were ccomprised of Latino farmworkers, small farm owners, and horticultural nursery workers. Other groups discussed in the SCCAHS paper were seafood industry workers and Extension agents. Given the nature of their occupation, Extension agents, who are employed either by a land-grant university or a county Extension office and liaise with their community, have connections to and are familiar with the state of AVRCs within their district. In the southeastern United States, many AVRCs must cope with natural disasters regularly. These natural disasters not only harm communities, crops, and livelihoods, but also can negatively impact the mental health of affected individuals including those living in AVRCs (NPR, 2019). The purposes of this document are to (1) provide tips on identifying specific individuals who could qualify as community leaders and (2) provide details on how partnering with community leaders can be beneficial for mental health communication and outreach.

\section{Current Challenges}

Extension agents in AVRCs are often directly involved with disaster preparation, prevention, and resiliency efforts. Given the close ties Extension agents have with disaster preparation and response, both physically and emotionally, these educators often suffer from negative mental health effects following a disaster, such as a hurricane. According to the SOS report, within the first 30 days following a disaster, signs of acute stress disorders may emerge and could later evolve into post-traumatic stress disorder, anxiety, and an array of other mental health conditions. In an SCCAHS pilot study that looked at the mental health impacts of Florida Extension agents from the most impacted counties following Hurricane Irma, Grattan (2019) found that "most participants $(\mathrm{n}=36)(55 \%)$ felt 'back to normal' four months post-impact" and " $20 \%$ were still feeling hurricane-related distress one-year post-landfall."

The first step in supporting AVRCs during and following a disaster is identifying signs of stress disorders. According to the American Foundation for Suicide Prevention (2020), common symptoms can include but are not limited to:

- Disengagement/withdrawal

1. This document is AEC721, one of a series of the Department of Agricultural Education and Communication, UF/IFAS Extension. Original publication date February 2021. Visit the EDIS website at https://edis.ifas.ufl.edu for the currently supported version of this publication.

2. Lisa Lundy, professor; Jacqueline Aenlle, graduate assistant; Ricky Telg, professor; Department of Agricultural Education and Communication; Tracy Irani, professor and department chair; Angie Lindsey, assistant professor; Department of Family, Youth and Community Sciences; Ashley McleodMorin, public relations specialist, UF/IFAS Center for Public Issues Education in Agriculture and Natural Resources (PIE Center); Michaela Kandzer, graduate assistant, Department of Agricultural Education and Communication; and Phillip Stokes, learning and org dev specialist, PIE Center; UF/IFAS Extension, Gainesville, FL 32611.

The Institute of Food and Agricultural Sciences (IFAS) is an Equal Opportunity Institution authorized to provide research, educational information and other services

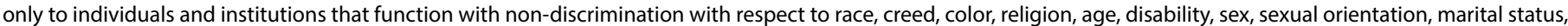

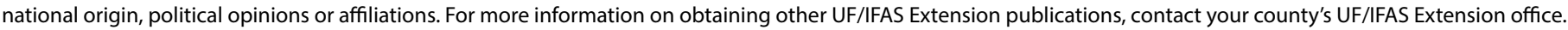
U.S. Department of Agriculture, UF/IFAS Extension Service, University of Florida, IFAS, Florida A \& M University Cooperative Extension Program, and Boards of County Commissioners Cooperating. Nick T. Place, dean for UF/IFAS Extension. 
- Increased substance use or abuse

- Aggression

- Fatigue

- Irritability

- Excess or insufficient amount of sleep

Once the signs of mental health disorders are identified, it is important to have mental health services available to communities coping with a natural disaster. AVRCs are historically difficult to reach with mental health and awareness efforts. Stacciarini et al. (2016) found residents in these communities often felt more comfortable when approached by individuals who held their trust, such as primary care physicians or church leaders.

\section{Potential Solutions}

Even when mental health services are available, many members of AVRCs feel uncomfortable or unsafe utilizing these services. A solution to this is to create partnerships with locally known, trusted individuals such as community leaders, worship leaders, and primary health care providers. Stacciarini et al. (2016) found that specific AVRCs "considered churches to be safe spaces, so much of [her] study recruitment occurred at churches."

The use of primary health care providers for collaborative outreach is not a new phenomenon. The collaborative care model, which involves nonmedical specialists working in tandem with primary care professionals, is used in previous research focusing on depression and mental illness (Gilbody et al., 2006).

\section{Conclusion and Recommendations}

Residents of AVRCs can experience several types of stress following a natural disaster, resulting in the development of negative coping strategies, such as the misuse of alcohol and opioids along with thoughts of suicide (Bolger et al., 1989; Jackson \& Sher, 2003; Centers for Disease Control and Prevention [CDC], 2018). Utilizing existing trusted partnerships to promote mental health services after a disaster may help individuals feel more comfortable in seeking help. Mental health care professionals should partner with trusted community members (i.e., church leaders, primary healthcare providers) to better serve these communities and gain their trust. These community leaders can then facilitate the creation and delivery of mental health workshops. One such workshop is the "Disaster Response and Recovery Mental Health" short course, developed by the University of Florida Institute of Food and Agricultural Sciences (UF/
IFAS) Department of Family, Youth and Community Sciences (FYCS) and the Florida State Agricultural Response Team (SART) to support those engaged in first responder work. More information on these workshops can be found at https://piecenter.com/2019/01/30/mental-health-workshops-to-prepare-natural-disaster-victims-and-responders/. Other similar workshops could be "adapted to educate a diverse array of professionals working in AVRCs, enhancing community support to connect people in AVRCs with mental health services" (Mitchell et al., 2020).

\section{References}

Abramson, D. M., Grattan, L. M., Mayer, B., Colten, C. E., Arosemena, F. A., Bedimo-Rung, A., \& Lichtveld, M. (2014). The resilience activation framework: A conceptual model of how access to social resources promotes adaptation and rapid recovery in post-disaster settings. Journal of Behavioral Health Services and Research, 42(1), 42-57. https://doi.org/10.1007/s11414-014-9410-2

American Foundation for Suicide Prevention. (2020, January 24). Risk factors and warning signs. Retrieved from https://afsp.org/risk-factors-and-warning-signs

Bolger, N., DeLongis, A., Kessler, R. C., \& Schilling, E. A. (1989). Effects of daily stress on negative mood. Journal of Personality and Social Psychology, 57(5), 808.

Centers for Disease Control and Prevention. (2018). Suicide rising across the US. Retrieved from https://www.cdc.gov/ vitalsigns/suicide/index.html

Gilbody, S., Bower, P., Fletcher, J., Richards, D., \& Sutton, A. J. (2006). Collaborative care for depression: A cumulative meta-analysis and review of longer-term outcomes. Archives of Internal Medicine, 21, 2314-2321. https://doi. org/10.1001/archinte.166.21.2314

Grattan, L. M., Lindsey, A. B., Liang, Y., Kilmon, K. A., Cohen, S., Irani, T., \& Morris, J. G. (2020). The shortand long-term impacts of Hurricane Irma on Florida agricultural leaders as early emergency responders: The importance of workplace stability. International Jounal of Environmental Research and Public Health, 17(3), 1050. https://doi.org/10.3390/ijerph17031050

Jackson, K. M., \& Sher, K. J. (2003). Alcohol use disorders and psychological distress: A prospective state-trait analysis. Journal of Abnormal Psychology, 112(4), 599-613. https://doi.org/10.1037/0021-843X.112.4.599 
Mitchell, R. C., Kandzer, M. S., Irani, T., Lindsey, A. B., Lundy, L. K., Telg, R. W., McLeod-Morin, A., Stokes, P., Chasek, C., Scheyett, A., Leeman, R., Stacciarini, J. M., Wennerstrom, A., Smithwick, J., Grattan, L., Dunleavy, K., Radunovich, H. L., Kane, A., Arosemena, F., \& Honeycutt, S. (2020). State of the Science: Mental Health Issues in Agricultural, Vulnerable and Rural Communities. SCCAHS2020/21-02. Gainesville, FL: University of Florida/ Southeastern Coastal Center for Agricultural Health and Safety. Retrieved from http://www.sccahs.org/wp-content/ uploads/2020/09/whitepaper2020_final1.pdf

Stacciarini, J. M. R., Vacca, R., Wiens, B., Loe, E., LaFlam, M., Pérez, A., \& Locke, B. (2016). FBO leaders' perceptions of the psycho-social contexts for rural Latinos. Issues in Mental Health Nursing, 37(1), 19-25. https://doi.org/10.310 9/01612840.2015.1076914

Sullivan, B., Caldwell, N., \& Shapiro, A. (2019).

Nearly 8 months after Michael, Florida Pan-

handle feels left behind. Retrieved from https://www. npr.org/2019/05/31/727905462/nearly-8-months-afterhurricane-michael-florida-panhandle-feels-left-behind 